\title{
38. EVOLUTION OF THE SOUTH PHILIPPINE SEA: DEEP SEA DRILLING PROJECT LEG 59 RESULTS
}

\author{
Robert B. Scott, Department of Geology, Texas A\&M University, College Station, Texas \\ Loren Kroenke, Hawaii Institute of Geophysics, University of Hawaii, Honolulu, Hawaii \\ Guram Zakariadze, ${ }^{1}$ Institute of Geology, Georgian Academy of Sciences, Tbilisi, U.S.S.R. \\ and
} Anatoli Sharaskin, Vernadsky Institute of Geochemistry, U.S.S.R. Academy of Sciences, 117334, Moscow, U.S.S.R.

\section{INTRODUCTION}

Several prominent inactive and active arcs and marginal basins lie within the confines of the South Philippine Sea (Fig. 1). These are, from west to east, the inactive West Philippine Basin, Palau-Kyushu Ridge, Parece Vela Basin, and West Mariana Ridge and the active Mariana Trough and Mariana Ridge. The two most acceptable hypotheses suggested for the origin of these marginal basins are (1) the entrapment of preexisting oceanic crust and (2) the formation of new oceanic crust by back-arc sea-floor spreading.

The former hypothesis-entrapment of old oceanic crust during initiation of subduction and island-arc formation, - was advocated by Hilde et al. (1977) for the West Philippine Basin. They suggested that the eastern boundary of the West Philippine Basin was a major transform fault that changed to a convergent plate boundary when Pacific plate motion shifted to a more westerly direction about 45 m.y. ago, creating the Palau-Kyushu arc and entrapping the West Philippine Basin.

The latter hypothesis-the generation of new crust by sea-floor spreading behind migrating arcs-was proposed by Karig (1975) for all the marginal basins of the South Philippine Sea. Essential to Karig's thesis is the proposal that throughout the evolution of the arcs and marginal basins of the South Philippine Sea, the Mariana Ridge has retained its role as the fore-arc region; that is, each time the arcs sundered, the same fore-arc region was displaced toward the east as the leading edge of the next-active island arc. If this thesis is correct, then the fragments of the geological record preserved in the fore-arc of the modern Mariana Ridge should indicate past volcanic activity of this fore-arc when it was part of the previously active Palau-Kyushu Ridge. Thus much of the deeply buried early volcanism on the Palau-Kyushu and West Mariana ridges may also be recorded in the Mariana Ridge.

Summaries of the events on the Mariana arc have been extracted from the work of Cloud et al. (1956), Schmidt (1957), Stark (1963), Tracey et al. (1964), and Ingle (1975), and from the results of DSDP Leg 60

\footnotetext{
${ }^{1}$ Present address: V. I. Vernadsky Institution of Geochemistry and Analytical Chemistry, U.S.S.R. Academy of Sciences, 117334 Moscow, U.S.S.R.
}

(Hussong, Uyeda et al., 1978). Only through an integration of all these investigations can a coherent evolution of the inactive arcs and marginal basins of the South Philippine Sea be constructed.

Because timing of events in the arcs and basins is fundamental to any evolutionary scheme, modern planktonic biozonation is used. The zonations used by Ingle (1975) on Leg 31, by Martini (this volume) on Leg 59, and by Hussong, Uyeda et al. (in press) on Leg 60, however, all differ somewhat. For a discussion of these differences see the biostratigraphic synthesis by Martini et al. (this volume).

\section{ASIAN PLATE BOUNDARY}

The Ryukyu arc, which forms the boundary between the Asian plate and the Philippine Sea (Fig. 1), contains both metamorphic and igneous Paleozoic rocks of island-arc affinities (Ingle, 1975) - glaucophane schists and andesites, for example. Thus, early in the evolution of the Pacific Ocean Basin, certainly long before the formation of the West Philippine Basin, the Ryukyu arc acted as an active convergent boundary along the eastern edge of the Asian plate. Since then, however, with the exception of some Paleocene to early Oligocene igneous activity also in the Ryukyu arc (Bowin and Reynolds, 1975), no volcanism occurred along that portion of the Asian plate boundary until late Miocene, when back-arc spreading began in the Okinawa Trough (Lee et al., in press).

\section{WEST PHILIPPINE BASIN}

Previous drilling at DSDP Sites 290 through 295 (Karig, Ingle, et al., 1975) suggests that the formation of the West Philippine Basin (Fig. 1) occurred during the early Tertiary. The basement ages determined from the drilling are not conclusive. The magnetic lineation pattern, often the best indicator of ocean-crust age, unfortunately permits multiple interpretations of the timing of basin formation in the case of the West Philippine Basin. For example, the anomaly identification of Louden (1976) points to basin formation between about 37 and $>52$ m.y., that of Watts et al. (1977) implies basin formation between about 40 and $>62$ m.y., and that of Shih (1978) suggests basin formation between about 25 and 56 m.y. According to Ben-Avraham et al. (1972), the oldest proposed age of formation is Mesozoic, which would require that the basin was formed by 


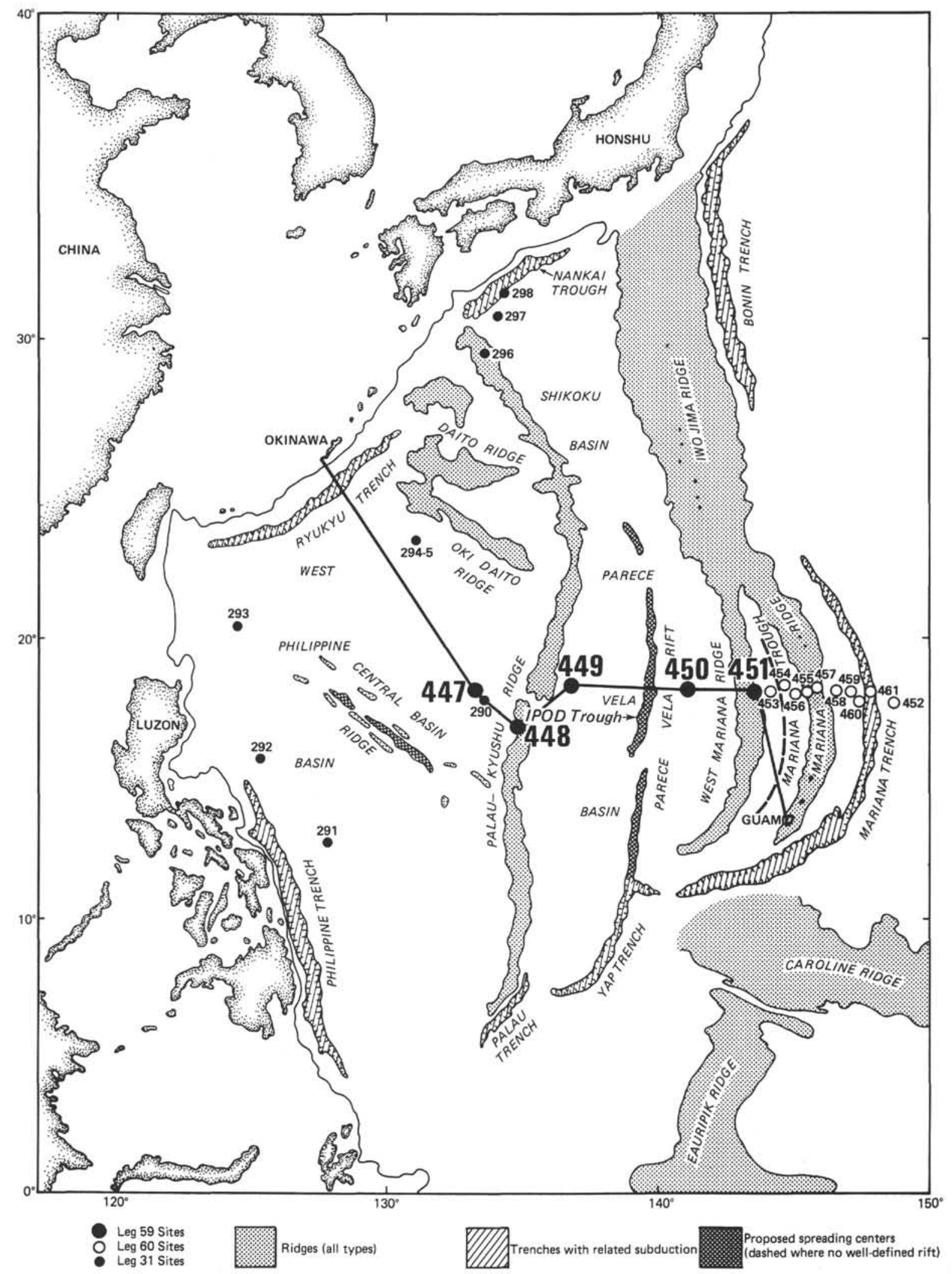

Figure 1. Map of the South Philippine Sea area. The Mariana Ridge is frequently referred to in the text as the Mariana arc. Also, different authors have referred to several geographic features by different names; e.g., the Central Basin Ridge is proposed here to avoid the genetic implications of the original name, the Central Basin Fault (Hess, 1948). The north-south trending elongate deep riftlike features centrally located in the Parece Vela Basin compose the Parece Vela Rift (Mrozowski and Hayes, 1979); one of the deeper troughs that make up the rift (which was transected on Leg 59) is the IPOD Trough. 
entrapment. Apparently, the low-amplitude magnetic anomalies formed at low latitudes do not permit unambiguous discrimination between the extremes of roughly 25 and 62 m.y. or even the Mesozoic magneticgeochronology postulated by Ben-Avraham et al.

There are, however, some relationships that do suggest a symmetrical back-arc-basin spreading origin of relatively young age for the West Philippine Basin: (1) The Central Basin Ridge, a rift-like feature with a central trough and slightly elevated ridges on either side (called the Central Basin Fault by Hess, 1948), has the bathymetric character of an extinct spreading center. (2) Although the magnetic anomaly pattern trends westnorthwest at a slightly oblique angle to the general northeast trend of the Central Basin Ridge, the rift itself seems to be offset by numerous small transform faults so that each rift segment actually is parallel to the anomaly pattern (Watts et al., 1977). (3) The magnetic anomaly pattern and low ridges and troughs in the basin are also parallel to the Oki Daito Ridge, giving credence to the suggested back-arc-basin origin. (4) Even though the 6000-meter water depth in the basin is typical of water depths found over Mesozoic oceanic crust, Sclater et al. (1976) have pointed out that the water depths over back-arc-basin crust of known age are deeper than those over oceanic crust of comparable age; the age versus depth curve of back-arc-basin crust is simply displaced downward about 800 meters below that of a normal oceanic crust. The depth of the West Philippine Basin falls on this displaced curve in conjunction with the proposed early Tertiary, as does the depth of the nearby Parece Vela Basin. (5) Sclater et al. (1976) suggested that this relationship requires a thinner crust. Although Murauchi et al. (1968) found no evidence to suggest that the South Philippine Sea has an abnormally thin crust, Langseth and Mrozowski (this volume) did find in the Site 447 survey area in the West Philippine Basin a $1.2-\mathrm{km}$-thick Layer $2(5.1 \mathrm{~km} / \mathrm{s})$ and a $2.7-\mathrm{km}$-thick Layer $3(6.8 \mathrm{~km} / \mathrm{s})$ underlain by a transition layer $(7.6$ $\mathrm{km} / \mathrm{s}$ ) to mantle. Karig (1974) has also suggested that the West Philippine Basin crust may be thin. In addition, on the basis of surface-wave analysis, Seekins and Teng (1977) have concluded that the lithosphere under the entire South Philippine Sea is thin and underlain by a low-velocity mantle. (6) The relatively high heat flow in the West Philippine Basin (Watanabe et al., 1977) suggests a young age for the basin; also the basin heatflow pattern fits the heat-flow versus age requirements of Sclater et al. (1976) for the early Tertiary. (7) Finally, the thin pelagic sediment cover in the central part of the basin also suggests a young age (Karig, Ingle, et al., 1975).

All the foregoing supports the conclusion that the West Philippine Basin was formed more or less symmetrically about the Central Basin Ridge by back-arcbasin spreading behind the Oki Daito Ridge during the early Tertiary, as suggested by Karig (1975). Direct evidence that the Oki Daito Ridge was an active arc during West Philippine Basin formation is lacking in DSDP Holes 294 and 295, but the concave upward slope along the southern boundary of the ridge is similar to that of a volcaniclastic apron (Harian, 1968).
Drilling results at Sites 446 and 445 in the basin and ridge north of Oki Daito Ridge, however, show limited sedimentological and igneous evidence of arc activity as long ago as the early Eocene (Klein, Kobayashi, et al., 1978a). Although the Oki Daito Ridge itself was not drilled, these results do make an arc role in the early history of the ridge probable. Whichever model of crustal generation is invoked for the formation of the West Philippine Basin, either back-arc basin or midocean ridge, spreading was active before the existence of the Palau-Kyushu arc. Moreover, when Pacific plate motion changed and subduction was initiated along the Palau-Kyushu boundary, some type of sea-floor spreading probably continued behind that boundary at a highly oblique angle to the Palau-Kyushu arc, producing an unusual ridge-trench-trench triple junction in that area of the sea floor. Today this junction is located in the vicinity of $13^{\circ} \mathrm{N}, 134^{\circ} \mathrm{W}$.

\section{Site 447}

If dating of West Philippine Basin basement could be used to anchor the magnetic anomaly lineations, then it might be possible to discriminate between an entrapment origin and a back-arc spreading origin for the basin. For this reason, DSDP Site 447 was located slightly to the west of DSDP Site 290, where the wedge of volcanic debris derived from the Palau-Kyushu Ridge is thin, affording the opportunity to reach and date the basement. Unfortunately, the sequence recovered at Hole 447A is neither a typical nor a complete pelagic sequence. Sediments younger than lower Miocene are missing. Below 47 meters of lower upper Oligocene to lower Miocene pelagic and calcareous clays, there are 40 meters of middle to upper middle Oligocene polymictic conglomerates and breccias and altered tuffs; below these, 26 meters of middle Oligocene volcaniclastic breccias and tuffs continue to basement. Although the tuffs seem to be part of the volcaniclastic wedge derived from the Palau-Kyushu arc, many cobbles in the middle Oligocene volcaniclastic breccias are obviously of the same lithology as the basement basalts. Moreover, although the paleontological age of these basal breccias is roughly 32 to 34 m.y., any of the aforementioned reconstructions based on the magnetic anomalies would require that basement at Site 447 be at least 4 m.y. older than this date. Thus a significant erosion surface may separate the breccias from igneous basement. In an attempt to resolve this problem, two of the freshest basalts from Hole $447 \mathrm{~A}$ were analyzed using ${ }^{40} \mathrm{Ar} /{ }^{39} \mathrm{Ar}$ dating methods (Sutter and Snee, this volume); neither sample met the criteria for a closed $\mathrm{K} / \mathrm{Ar}$ system, leaving the basement age indeterminate.

Although the sedimentary record at Site 447 is ambiguous regarding the age of the West Philippine Basin crust, it does contain evidence for tectonism on the eastern side of the basin that coincides with the last period of volcanic activity on the adjacent PalauKyushu Ridge. Middle Oligocene coarse volcaniclastic breccias containing clasts of the same composition as the underlying basaltic basement are present at the base of the sedimentary section. Their presence, in conjunction with the magnetic anomaly evidence, suggests that 
local tectonism triggered erosion of preexisting normal pelagic sediments before deposition of these volcaniclastic breccias took place. In addition, rare, displaced lower Oligocene nannoplankton are present in the middle Oligocene strata, indicating erosion of older deposits. Accumulation of this breccia sequence was both interrupted by deposition of tuffaceous debris and followed by deposition of tuffs; these tuffs probably were derived from middle Oligocene volcanism from the then-active Palau-Kyushu Arc. Higher in the sedimentary sequence, middle to lower upper Oligocene polymictic breccias and conglomerates contain increasing percentages of calcareous biogenous sediment and decreasing percentages of tuffaceous debris, as well as displaced lower Oligocene nannoplankton. These later deposits probably represent the downslope movement of sediments in response to recurring tectonism on the Palau-Kyushu arc between 26 and 32 m.y. ago.

From the preservation of nannofossils in the sediments, it is estimated that the basal volcaniclastic breccias were deposited below or close to the carbonate compensation depth (CCD) but that the overlying polymictic breccias and conglomerates were deposited above the CCD, suggesting uplift in the vicinity of Site 447 in the late middle Oligocene. The lower to upper Oligocene sedimentary sequence at Hole 290 (Karig, Ingle, et al., 1975 ) points to a similar history of tectonism and arc volcanism, except that in Hole 290 there is evidence of tectonism as early as $37 \mathrm{~m} . y$. ago. Following a quiescent period of deposition of calcareous pelagic clays and silts, both Sites 447 and 290 subsided below the CCD sometime after the early late Oligocene to accumulate pelagic clays.

The chemistry of the basement basalts can reveal certain magmatic affinities indicative of tectonic environments (Hawkins, 1977). The basaltic basement complex consists of 80 meters of basalts with 18 flow units having 5 individual magma chemistries (Mattey et al., this volume; Zakariadze et al., this volume). Although the differences in chemistry are distinct, the units fall within the compositional range of typical mid-ocean ridge (MOR) basalt. Only two magma types are recognized; one type is characterized by low $\mathrm{Ti} / \mathrm{Zr}$ ratios and the other by higher ratios. Within each of these magma types, chemical differences can be related by fractionation schemes. Mattey et al. concluded that the differences between these two magma types, however, cannot be explained by crystal fractionation; rather, either differing degrees of partial melting or slightly different source compositions produced magmas with different $\mathrm{Ti} / \mathrm{Zr}$ ratios. The initial ${ }^{87} \mathrm{Sr} /{ }^{86} \mathrm{Sr}$ values measured for these basin basalts (Armstrong and Nixon, this volume) -0.70254 to 0.70269 , averaging 0.70261 -are low and within the range of MOR basalt values (Hart, 1971; White and Bryan, 1977). All these observations and conclusions are in accord with those of MOR basalt characteristics (Blanchard et al. 1976; Erlank and Kable, 1976; Rhodes et al., 1976; Dungan and Rhodes, 1978; Wood, Varet, et al., 1979; Wood, Tarney, et al., 1979); thus the magmatic processes that formed the West Philippine Basin were probably similar to those that formed mid-ocean ridge basalts. However, these chemical characteristics of MOR basalt are not exclusive; they also overlap with several examples of backarc-basin chemical characteristics (Hawkins, 1976 and 1977; Wood et al., this volume; Mattey et al., this volume). The West Philippine Basin basalt chemistry from Hole 447A therefore cannot be used to discern whether the basin basement consists of entrapped MOR basalts or of back-arc-basin basalts.

We conclude that the West Philippine Basin was formed by sea-floor spreading about the Central Basin Ridge between approximately 60 and $37 \mathrm{~m} . y$. ago. But we cannot distinguish whether this process resulted from back-arc spreading or entrapment of a mid-ocean ridge spreading center; whatever the case, the formation of this basin was roughly coincident with an apparent early Tertiary pause in volcanism along the Philippine and the Ryukyu arcs (Ingle, 1975; Bowin and Reynolds, 1975). If a back-arc spreading origin is accepted, then spreading continued obliquely behind the Palau-Kyushu Ridge between 42 and 37 m.y. ago; if an origin of entrapment of young crust is accepted, then the continued spreading about the Central Basin Ridge is a remnant of previous northward Pacific plate motion. The young magnetic age Shih (1978) assigned to the basin-25 to 56 m.y.-is considered unlikely, because spreading in the West Philippine Basin would have continued after the Palau-Kyushu arc was sundered and Parece Vela Basin spreading was initiated. Thus the formation of the West Philippine Basin most likely took place no later than 37 m.y. ago, as Louden's (1976) anomaly identification indicates. Tectonic disturbances and uplift affected the basement and disrupted sedimentation on the eastern side of the West Philippine Basin close to the PalauKyushu Ridge between about 34 and 26 m.y. ago. It should be noted that the geophysical and geologic data used to reach these conclusions are, at best, beset by ambiguities; thus these conclusions must be considered speculative. Certainly the undefined geologic and magnetic age of the basin, the unusual attitude of the spreading center relative to the Palau-Kyushu remnant arc, and the abnormally thin crust all need further investigation.

\section{PALAU-KYUSHU RIDGE}

The Palau-Kyushu Ridge forms the boundary between the 6-km-deep West Philippine Basin and the 5-km-deep Parece Vela Basin, standing more than 3 and $2 \mathrm{~km}$, respectively, above each of the basin floors (Fig. 1). As mentioned earlier, this boundary apparently has played a dual role: first, that of a large transform fault prior to 45 m.y. ago (Hilde et al., 1977) and second, that of a convergent margin following the change in Pacific plate motion after that time. From the sedimentary record supplied by Holes 290 and 296, Karig (1975) considered the ridge to be a remnant arc that was active between the middle Oligocene to early Miocene. Hole 296, however, never reached arc basement, and this portion of the ridge, over $1500 \mathrm{~km}$ north of the central part of the Palau-Kyushu Ridge, shows evidence of termination of volcanism about 25 m.y. ago (Karig, 1975), close to 
the time of the initial opening of the Shikoku Basin, according to magnetic anomaly identification (Watts and Weissel, 1975; Shih, in press). Holes 448 and 448A were drilled at about $16^{\circ} \mathrm{N}$ on the western side of the ridge to establish the nature and timing of volcanism in the central part of the ridge. The timing of the volcanic activity of the remnant arc is critical to the evolution of the West Philippine Basin; presumably the cessation of PalauKyushu volcanism should have coincided with the time of arc sundering and initiation of spreading that formed the Parece Vela Basin (Karig, 1975).

\section{Site $\mathbf{4 4 8}$}

Site survey dredging on the Palau-Kyushu Ridge recovered highly vesicular volcanic rocks suggestive of shallow-water or even subaerial arc volcanism. Moreover, the International Working Group on the IGCP Project "Ophiolites" (1977) dredged igneous rocks from the Palau-Kyushu Ridge that had petrological trends typical of island arcs and concluded that volcanism ceased during the Oligocene. Murauchi et al. (1968) found the thick crust of the Palau-Kyushu Ridge to consist of a $2.5-\mathrm{km}$-thick, $3.5-\mathrm{km} / \mathrm{s}$ layer, overlying a 2.9-km-thick, $5.7-\mathrm{km} / \mathrm{s}$ layer, in turn overlying a 3.6 $\mathrm{km}$-thick, $6.6-\mathrm{km} / \mathrm{s}$ Layer 3. Thus a normal oceanic lower crust seems to be overlain by $5.4 \mathrm{~km}$ of upper crust, presumably of both normal oceanic and islandarc origin.

In Holes 448 and $448 \mathrm{~A}$, below the nannofossil sediments and tuffs, a sequence of basalts and intervening volcaniclastic breccias was encountered that has measured velocities in the range of the $3.5-\mathrm{km} / \mathrm{s}$ layer recognized by Murauchi et al. (1968) and that probably represents arc basement. The pillow basalts that form the arc basement at Holes 448 and $448 \mathrm{~A}$ are undoubtedly arc tholeiites (Scott, this volume; Mattey et al., this volume). Numerous petrological indicators of arc tholeiites are present: (1) Vesicles form up to $30 \%$ of the volume of the basalts and clasts in abundant volcaniclastic units. (2) The glasses show evidence of marked iron enrichment typical of tholeiites and fall into Miyashiro's (1974) classification of arc tholeiites. (3) The REE pattern is relatively flat, with only a small depletion of La (Jakeš and Gill, 1970); and the relatively low $\mathrm{Sr}, \mathrm{Ba}$, and $\mathrm{Al}_{2} \mathrm{O}_{3}$ values all appear to classify the basalts as arc tholeiites rather than as rocks of the calc-alkalic series (Jakeš and White, 1972). (4) The plagioclase-clinopyroxene-orthopyroxene-pigeonitemagnetite phenocryst assemblages are typical of arc tholeiites rather than MOR basalts. (5) Finally, the initial ${ }^{87} \mathrm{Sr} /{ }^{86} \mathrm{Sr}$ ratios of 0.70356 and 0.70333 determined by Armstrong and Nixon (this volume) are slightly less radiogenic than the modern Mariana arc average of 0.7037 (Meijer, 1976) but similar to those found in andesites of Agrigan, a northern Mariana Island, which average 0.7033 (Stern, 1979).

Evidence to suggest that Palau-Kyushu volcanism may have evolved from an initial tholeiitic stage to a calc-alkalic stage comes from studies of rocks dredged by the International Working Group on the IGCP Project "Ophiolites" (1977). High $\mathrm{Al}_{2} \mathrm{O}_{3}$ values (19.4 and
$19.0 \mathrm{wt} . \%$ ) and $\mathrm{Sr}$ values ( 340 and $270 \mathrm{ppm}$ ) of samples from their Dredge Sites 1396 and 1397 seem to suggest calc-alkalic affinities, but the rocks are altered (during low temperature sea-water alteration the $\mathrm{Sr}$ content may readily increase). Also the high $\mathrm{Al}_{2} \mathrm{O}_{3}$ values may reflect plagioclase crystal segregation or clay mineral formation. Also Migdisov (this volume) suggests that, on the basis of major-element chemical criteria, calc-alkalic magmas were the source of ashes and tuffs found in the sedimentary sequence above the uppermost lavas. The low average $\mathrm{Al}_{2} \mathrm{O}_{3}(13.7 \%), \mathrm{Ba}(49 \mathrm{ppm})$, and $\mathrm{Sr}$ (169 $\mathrm{ppm}$ ) values reported by Migdisov (this volume), however, are more typical of the averages for the underlying arc tholeiites than for calc-alkalic rocks. Thus most of the lavas and pyroclastic products appear to be tholeiitic, and evidence of calc-alkalic character is sparse or absent.

These highly vesicular basalts and volcaniclastic units are readily altered by ambient temperature sea-water weathering (Scott, this volume; Wood et al., this volume) near the top of the igneous units, but show mineralogical and isotopic evidence of higher temperature alteration toward the base of the section (Aldrich et al., this volume). Clay mineral products of alteration are kaolinite-rich at the top of the volcaniclastic section, whereas smectite-vermiculite-chlorite mixed-layer clays are more typical lower in the section. Oxygen isotope data on clay mineral alteration products suggest that a temperature differential as great as $170^{\circ} \mathrm{C}$ may have existed in the arc basement portion of the sequence, requiring approximately nine times the normal geothermal gradient; this possibility correlates well with the observation of abundant sills and dikes lower in the sequence of igneous and volcaniclastic units. Native copper is abundant in igneous and volcaniclastic units except where it is replaced by sulfides near intrusive units.

The sedimentary record is relatively simple, both in the 17 volcaniclastic breccia units within the arcbasement complex and the 5 units above the basement. Accumulation rates in the arc basement exceed 300 $\mathrm{m} / \mathrm{m} . \mathrm{y}$., and nannofossil assemblages are recognizable to depths of 805 meters sub-bottom. Both the nannofossil age of volcaniclastic breccias within the arcbasement complex (NP23, 32-34 m.y., Martini et al., this volume) and the ${ }^{40} \mathrm{Ar} /{ }^{39} \mathrm{Ar}$ date of the intervening lavas $(32.3 \pm 2.2$ to $33.4 \pm 2.6$, Sutter and Snee, this volume) agree remarkably well. Above the uppermost pillow lava, a decrease in the dilution effect of tuffs resulted in lower accumulation rates of nannofossil chalks from the lowest upper Oligocene. According to the breaks in lithology and accumulation rates of tuffs above the arc basement, the last significant volcanism on the Palau-Kyushu Ridge ceased by the middle Oligocene/late Oligocene boundary ( 29 m.y. ago). Nannofossil chalks and oozes of the upper Oligocene to middle Miocene have no significant volcanogenic component. Because calcareous nannofossils are found throughout the sequence, the ridge must have remained above the $\mathrm{CCD}$ throughout its depositional history. In the uppermost ooze, however, preservation of planktonic foraminifers is poor, suggesting that this unit was deposited 
near the foraminiferal lysocline, which, in turn, suggests that subsidence occurred in the middle Miocene. The absence of younger sediments at the drill site may indicate that ocean currents of significant erosive power exist today in the intermontane troughs of the PalauKyushu Ridge.

The following sequence is thus proposed for the formation of the Palau-Kyushu Ridge: (1) After the change in direction of plate motion in the Pacific and after conversion of the large transform fault boundary on the eastern side of the West Philippine Basin to a subduction zone, arc volcanism was initiated and the PalauKyushu Ridge was constructed on top of normal oceanic crust. (2) An arc-basement complex, consisting of about $2.5 \mathrm{~km}$ of low-velocity flows, sills, dikes, and volcaniclastic breccias, was built above $2.9 \mathrm{~km}$ of intermediate velocity crust that probably consists of Layer 2-type ocean crust thickened, perhaps, by arc-related intrusives. The arc construction process must have persisted from about 42 m.y., based on evidence from Guam, Saipan, and Tinian islands (Cloud et al., 1956; Schmidt, 1957; Stark, 1963; Tracey et al., 1964; Ingle, 1975), to 32 m.y. ago (Fig. 2). (3) About 32 m.y. ago, the volcanism began to decrease, stopping by 29 m.y.; this probably represents the time of sundering of the arc along the volcanic axis. The Palau-Kyushu fore-arc region moved eastward and became the precursor of the West Mariana fore-arc, leaving behind the western remnant arc, the Palau-Kyushu Ridge. (4) Tilting of the strata seems to have occurred in two periods; after deposition of the arc-basement complex, about $20^{\circ}$ of post-middle Oligocene tilting occurred, and after deposition of interlayered tuffs and chalks another $20^{\circ}$ of late Oligocene to early Miocene tilting occurred. (5) Nannofossil chalks and oozes show no indication of tectonic disturbance except for the slow subsidence that took place in the middle Miocene.

\section{PARECE VELA BASIN}

The Parece Veal Basin is considered to have been formed by back-arc spreading in early Miocene (Karig, 1975), when the Palau-Kyushu arc was sundered to form the Palau-Kyushu Ridge and the West Mariana Ridge (Fig. 1). The age of igneous basement, however, was not satisfactorily determined by the drilling results of Holes 53 and 54 on DSDP Leg 6 (Fischer, Heezen et al., 1971), and the existing magnetic anomaly data were not readily interpretable, because low-amplitude anomalies formed at low latitudes characterize the basin. Like the West Philippine Basin, the Parece Vela Basin is about 800 meters deeper than ocean crust of similar age (Sclater et al., 1976). The north-south trending Parece Vela Rift bisects the basin (Fig. 1) and is the proposed fossil spreading axis (Langseth and Mrozowski, this volume). The IPOD Trough, a 6000-meter-deep isolated segment of the Parece Vela Rift, was crossed during the $18^{\circ} \mathrm{N}$ transect of the Parece Vela Basin by Leg 59 (Fig. 2 ). Although sediments are rather thin on the western side of the basin, a thick wedge of sediments from the West Mariana Ridge has inundated the irregular basement topography on the eastern side of the basin to the extent that, in places, the Parece Vela Rift is filled. In order to determine basement age and mechanism of basin formation, two holes were drilled in the Parece Vela Basin-one at Site 449 on the western side of the basin close to the Palau-Kyushu Ridge and one at Site 450 on the eastern side of the basin close to the IPOD Trough.

Before these holes were drilled on Leg 59, the petrological nature of the Parece Vela Basin was poorly known. Igneous rocks at Sites 53 and 54 (Fischer, Heezen, et al., 1971) were both drilled on structural highs within the thick wedge of sediments of the West Mariana Ridge; although according to geophysical evidence these highs were interpreted as uplifted basement blocks, the rocks recovered in Hole 53 were interpreted as intrusive basalt and andesite (Fischer, Heezen, et al., 1971; Ridley et al., 1974). The common occurrence of basaltic intrusions in the Shikoku Basin (Dick, in press; Dick et al., in press; Klein, Kobayashi, et al., in press) supports the conclusion that intrusive bodies may be present in the Shikoku-Parece Vela basin complex and leaves the interpretation of the emplacement mechanism of the Hole 54 basalt open to question. Alteration of Hole 53 rocks (Fischer, Heezen, et al., 1971) also casts doubt upon the validity of the presence of andesite, particularly as Dick et al. (in press) found the chemistry of the Shikoku Basin basalts indistinguishable from MOR basalt chemistry, except for high abundances of volatiles. Dredged basalts and gabbros from the basin (Dietrich et al., 1978) are similar to MOR basalts; and they are even more similar to the Lau Basin basalts than to Mariana Trough basalts (Site 450, Chapter 5, this volume; Hawkins, 1977).

\section{Site 449}

The basement in the western Parece Vela Basin, in the vicinity of Site 449 , is very irregular and is considered by Murauchi et al., (1968) to consist of a low velocity $(3.1-3.7 \mathrm{~km} / \mathrm{s}$ ) Layer 2 a overlying a more normal velocity $(4.3-5.1 \mathrm{~km} / \mathrm{s})$ Layer $2 \mathrm{~b}$. Sonobuoy refraction profiles give velocities for Layer 2 of 4.5 to 5.3 $\mathrm{km} / \mathrm{s}$ and velocities for Layer 3 between 6.2 and 6.8 $\mathrm{km} / \mathrm{s}$ and indicate a highly variable thickness for Layer 2 (from 0.9-2.0 km). The interpretation of the site survey magnetic anomaly patterns in the western Parece Vela Basin (see Langseth and Mrozowski, this volume) suggests that the Parece Vela Basin formed between about 30 and 18 m.y. ago, some 5 m.y. after the Shikoku Basin (Shih, in press).

Drilling at Site 449 reveals that based on paleontology, the basement is about 24 m.y. old; this estimate agrees relatively well with the age of 26 m.y., indicated by the presence of Magnetic Anomaly 7A at the site. The pillow basalts recovered in Hole 449 have mineralogies and whole-rock major- and trace-element chemistries indistinguishable from those of MOR basalts (Mattey et al., this volume; Zakariadze et al., this volume). Mattey et al., consider these basalts most similar to those basaltic units recognized in Hole 447 by their low $\mathrm{Ti} / \mathrm{Zr}$ ratios. Although the sedimentary units encountered in Hole 449 make up a more or less normal oceanic 


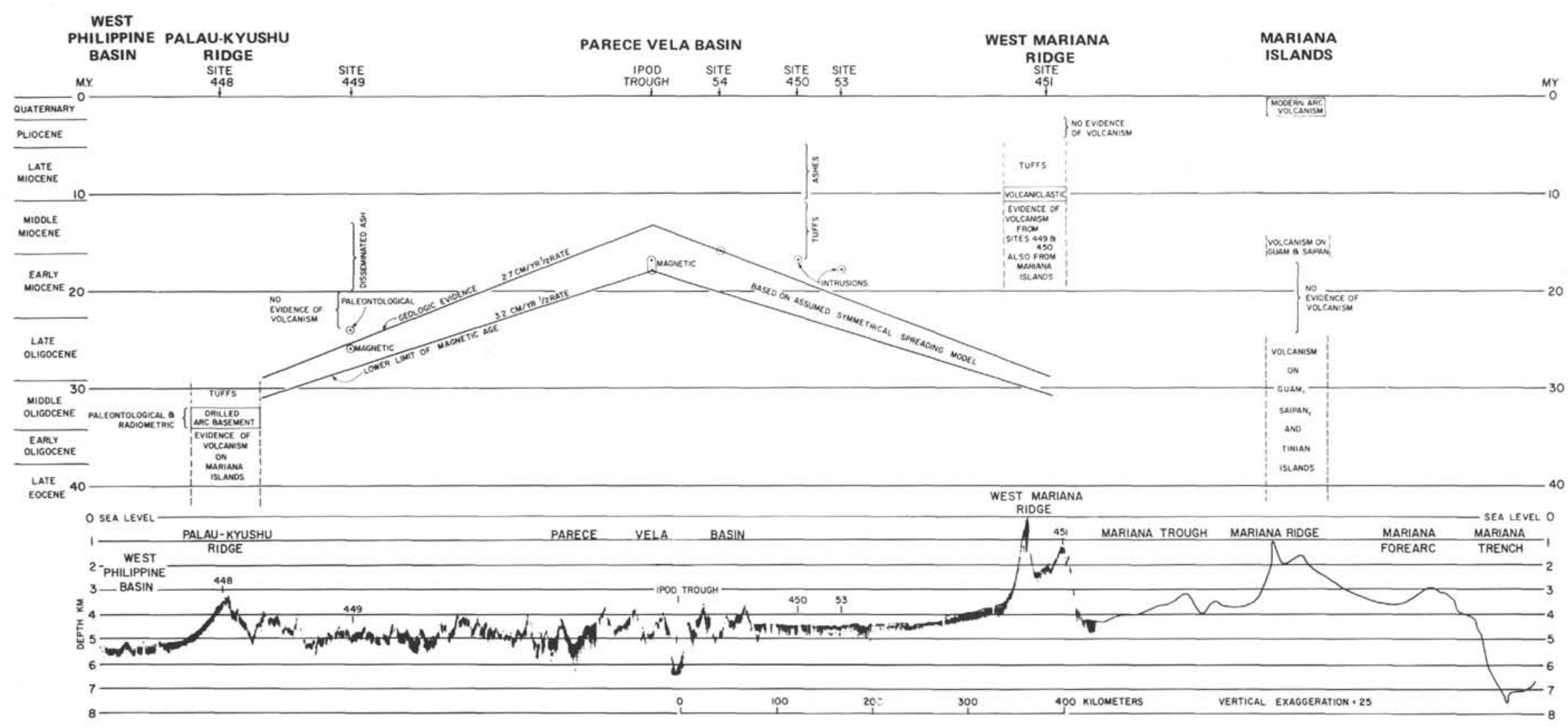

Figure 2. Time-distance graph of back-arc-basin spreading and arc volcanism in the South Philippine Sea projected above the bathymetric profile across the region along the $18^{\circ} \mathrm{N}$ latitude- (Between the Mariana Trough and the West Philippine Basin, a seismic reflection profile made during Leg 59 site surveys has been inserted at a vertical exaggeration of 25 . On the time-distance graph, the dashed vertical lines indicate probable times of volcanism, the solid boxes represent known periods of volcanism, and the sloping lines indicate spreading in the Parece Vela Basin. Spreading of the Mariana Trough [5 m.y. ago to present, Hussong, Uyeda, et al., 1978] is not shown.) 
pelagic sequence, some unusual features are observed. The basal sediments have higher-than-average, Pacific clay, metal/aluminum ratios requiring metal input, presumably from hydrothermal activity in young marginal basin crust (Scott and Bolger, this volume). The basal sedimentary unit is a nannofossil ooze deposited from the late Oligocene to early Miocene, overlain by a pelagic clay deposited during the early Miocene. This suggests that as basin subsidence occurred from late Oligocene to early Miocene, the sea floor sank below the CCD, as expected in normal marginal basin evolution. Higher in the section, middle Miocene layers of nannofossil ooze alternate with radiolarian ooze and pelagic clay. The oozes have sharp lower boundaries and contain pumice clasts. The middle Miocene to Pleistocene uppermost unit consists only of pelagic clay.

Several explanations have been postulated to explain these reoccurring nannofossil oozes in the pelagic clay sequence: (1) Tectonic uplift and subsidence cycles repeated over short intervals of time could explain such a sequence, if the movements carried the sea floor past the CCD. This cyclic tectonism would have to have started about 16 m.y. ago with an uplift of about 400 meters or more, according to the age-depth relationship (Sclater et al., 1976) of the marginal basins. (2) Repeated fluctuations of the CCD by as much as 400 meters would be another possible explanation. (3) Alternatively, and it seems more likely turbidity currents caused by slumping of sediments from nearby higher regions could have supplied the nannofossil oozes to the sequence. The generally sharp, as opposed to gradational, bases of the oozes support the last contention.

Events recorded in Hole 449 can be summarized as follows (Fig. 2): (1) Tholeiitic pillow basalts indistinguishable from MOR basalts were extruded between 26 and 24 m.y. ago, forming the uppermost layer at the site. (2) At least 24 m.y. ago, nannofossil oozes accumulated; these sediments contained no volcanic debris even though the sundered fore-arc at this time was only roughly $90 \mathrm{~km}$ farther eastward; there is strong evidence of an absence of abundant pyroclastic volcanism on the arc during this period. (3) The region submerged below the CCD about $21 \mathrm{~m} . \mathrm{y}$. ago, and only pelagic clay accumulated. (4) A distinct influx of disseminated ash in the sediments occurred about 20 m.y. ago, indicating that abundant pyroclastic volcanism along the West Mariana arc had begun and was affecting the western half of the Parece Vela Basin. (5) Dilution of pelagic clay caused by the renewed accumulation of biogenous oozes occurred between 16 and $14 \mathrm{~m} . y$. ago. (6) The last significant influx of volcanic debris occurred roughly $13 \mathrm{~m} . \mathrm{y}$. ago at Site 449 , marking cessation of West Mariana arc volcanism. (7) After this time to the present, deposition of pelagic clay has been uninterrupted.

\section{Site $\mathbf{4 5 0}$}

A thick wedge of sediments extends across most of the eastern side of the Parece Vela Basin westward from the West Mariana Ridge (Fig. 1), progressively inundating the rough basement until dammed by a series of north-south trending ridges near the IPOD Trough. In the eastern part of the survey area, acoustically wellstratified sediments are more than $0.6 \mathrm{~km}$ thick, and basement is indiscernable in the single-channel reflection profiles. Deep sedimentary and basement structures are revealed by multichannel profile work; on the basis of the observed stratigraphic relationships, Langseth and Mrozowski (this volume) suggest that the sediments were implaced by bottom flow from the east. Gentle undulations observed in the deep sediments may be related to post-basement-formation faulting; the uppermost pelagic sediments appear to be simply draped over the undulatory sequences.

Sonobuoy refraction measurements in the survey area for Site 450 range from 1.65 to $2.05 \mathrm{~km} / \mathrm{s}$ for the sediment layers, average $5.4 \mathrm{~km} / \mathrm{s}$ for the top of Layer 2 , and range from 6.0 to $6.7 \mathrm{~km} / \mathrm{s}$ for the top of Layer 3 (Langseth and Mrozowski, this volume). Both site surveys and the study of Murauchi et al. (1968) indicate normal oceanic crustal structure. As was mentioned before, both Holes 53 and 54 drilled on Leg 6, were intended to penetrate through the sediment wedge into the uplifted basement blocks. In the case of Hole 53, the "basement" was found to be an intrusion about 18 m.y. old (Fischer, Heezen, et al., 1971); in the case of Hole 54 , basement was dated paleontologically as 16 m.y. old. Both dates seem 4 to 5 m.y. too young to match predicted magnetic isochrons associated with symmetrical spreading, yet Hole 53 seems to be about $6 \mathrm{~m}$.y. too old to fit a possible asymmetric spreading origin (Fig. 2). In Hole 450, the upper Miocene to Pleistocene pelagic clay of the uppermost unit, about 26 meters thick, probably represents the thin layer that drapes over the aforementioned undulatory sequence; Karig (1971) also recognized such a draped shallow reflector in DSDP Leg 6 surveys. The underlying middle to upper Miocene unit consists of about 84 meters of interbedded ash and pelagic clay. Middle Miocene fine vitric tuffs, vitric tuffs, and rare tuffaceous volcaniclastic conglomerate, nearly 350 meters thick, are intruded at the base by pillowed igneous rocks. A sample of the pillowed rocks studied by conventional $\mathrm{K} / \mathrm{Ar}$ and ${ }^{40} \mathrm{Ar} /{ }^{39} \mathrm{Ar}$ methods gave data that do not meet the criteria for a closed $\mathrm{K} / \mathrm{Ar}$ system (Sutter and Snee, this volume). The hydrothermally altered contact metamorphic aureole, the baked and leached zone, and the small protrusions of lava that ruptured the glassy pillow margins to intrude into the leached zone all attest to a shallow subsediment pillow lava intrustion into an unconsolidated slurry of volcanic ash and sea water. Clearly, the igneous sedimentary contact requires an intrusive origin for the igneous rocks, even though pillow lavas were formed. This conclusion is in agreement with those reached for the nearby Site 53 and Sites 442 to 444 in the Shikoku Basin (Klein, Kobayashi, et al., in press and 1978b). Apparently, off-axis magmatic activity is relatively common, at least in this marginal-basin complex.

The major- and trace-element chemistry of the Hole 450 tholeiitic basalts is indistinguishable from that of MOR basalts (Mattey et al., this volume; Zakariadze et al., this volume), but the trace elements are somewhat 
distinctive when compared to those of Site 449. The Hole 450 basalts have higher Ti, Y, Zr, and Ce but lower $\mathrm{Sr}$ and $\mathrm{Ba}$ than those of Hole 449. In this regard, Hole 450 basalts are also similar to those of the Shikoku Basin (Dick et al., 1978), even though Hole 450 basalts are not as highly vesicular as are those of the Shikoku Basin.

Events recorded in Hole 450 can be summarized as follows: (1) A tholeiitic magma intruded more than 300 meters of tuff nearly to the surface of the rapidly accumulating sediment wedge at a time close to the age of the sediments ( 17 m.y.) several million years after symmetrical spreading formed the basin crust (Fig. 2). (2) About $11 \mathrm{~m} . y$. ago, the rapid influx of volcanogenic turbidites derived from the West Mariana Ridge began to decrease. (3) Between 9 and 5 m.y. ago, the Parece Vela Basin was cut off from the source of volcanic debris on the West Mariana Ridge; Rodolfo (this volume) considers these debris to be epiclastic, and thus they may not be indicative of continued volcanism during this period. (4) At about the same time, deformation of the back-arc region created basement faults that folded overlying sediments; the back-arc region subsided below the CCD, thereafter to accumulate only pelagic clay.

\section{WEST MARIANA RIDGE}

The precipitous escarpments on the eastern side of the West Mariana Ridge appear to be the physiographic expression of the large-scale normal faulting that must have occurred during the sundering of the arc (Karig, 1975). Prior to drilling Hole 451 on the eastern side of the remnant arc (Fig. 1), petrologic knowledge of the West Mariana Ridge was limited to interpretations of dredged samples; Karig and Glassley (1970) consider vesicular dacite and Pliocene sandstone dredged from the ridge to be evidence of young, shallow volcanism. Structurally the ridge appears to be similar to the PalauKyushu Ridge. From a refraction profile about $500 \mathrm{~km}$ north of Site 450, Murauchi et al. (1968) found the ridge to consist of a $3-\mathrm{km}$-thick section of $3.5-\mathrm{km} / \mathrm{s}$ material, overlying a 4.6 to $5.5-\mathrm{km} / \mathrm{s}$ layer.

\section{Site 451}

Refraction profiles obtained during the survey indicate that $1 \mathrm{~km}$ of sediment, with a velocity of $2 \mathrm{~km} / \mathrm{s}$, overlies $1.5 \mathrm{~km}$ of arc basement, with a velocity of 4 $\mathrm{km} / \mathrm{s}$, which, in turn, overlies a layer with a velocity greater than $5 \mathrm{~km} / \mathrm{s}$ (Langseth and Mrozowski, this volume). These results agree well with the semblance calculations on the multi-channel seismic reflection data in the vicinity of Site 451, which indicate that approximately 700 meters of sediment overlie a $3.9-\mathrm{km} / \mathrm{s}$ arc basement.

Over 925 meters of sedimentary material were drilled at Hole 451. The sequence consists of 36 meters of upper Miocene ash and tuff, which, in turn, overlies about 860 meters of upper Miocene volcaniclastic breccias and conglomerates and tuffs. Below 926 meters sub-bottom, however, both slower drilling rates and recovery of pillow basalt fragments to 930 meters sub-bottom suggests that the arc basement was just reached. Most of the volcaniclastic breccia consists of highly vesicular basaltic to andesitic debris, which is typical of shallowwater or subaerial volcanic activity. Sedimentary structures also indicate that the debris was introduced by slumping from nearby higher elevations. Moreover, the occurrence of shallow-water corals, large foraminifers, and fragments of lignite in some of the debris flows suggest that very shallow to slightly emergent conditions had existed in the source area. In fact, in the southwestern part of the site survey area, a flat-topped seamount is only 73 meters below the surface.

Volcanic debris from the West Mariana Ridge appears to be more evolved petrologically than the moreprimitive arc tholeiites of the Palau-Kyushu Ridge. Chemical studies of clasts in the volcaniclastic debris from Hole 451 indicate that all 9 samples studied by XRF methods appear to have calc-alkalic affinities with generally high average $\mathrm{Al}_{2} \mathrm{O}_{3}(18.2 \%), \mathrm{Sr}$ (512 ppm), and $\mathrm{Ba}(184 \mathrm{ppm})$ value and a high average chondrite normalized $\mathrm{Ce} / \mathrm{Y}$ ratio (1.9). Clearly these contrast with the average of $\mathrm{Al}_{2} \mathrm{O}_{3}(14.0 \%), \mathrm{Sr}(169 \mathrm{ppm})$, and $\mathrm{Ba}$ (49 $\mathrm{ppm}$ ) values and the average $\mathrm{Ce} / \mathrm{Y}$ ratio $(0.9)$ for PalauKyushu tholeiitic basalts. The silica content of 8 of 9 samples is between $48.2 \%$ and $50.6 \%$ and thus they can be considered basalts; only one with $57.2 \% \mathrm{SiO}_{2}$ can truly be called an andesite. Although alteration of Hole 451 volcaniclastic breccias does not seem to be as pronounced as that of volcaniclastic breccias from Holes 448 and 448A (Aldrich et al., this volume), the green clay identified as a smectite-vermiculite-chlorite mixedlayer clay is abundant in the lower few hundred meters of Hole 451, together with disseminated native copper.

Based upon drilling results and previous surveys, the probable sequence of events for the development of the West Mariana Ridge is as follows (Fig. 2): (1) By about $11 \mathrm{~m} . \mathrm{y}$. ago, the arc-basement complex, consisting of approximately $1.5 \mathrm{~km}$ of eruptive material, had been constructed on top of a $5.5-\mathrm{km} / \mathrm{s}$ oceanic Layer 2 at Site 451. (2) During the next 1.5 m.y., volcanic activity continued, building subaerial volcanic edifices and depositing about 740 additional meters of volcaniclastic debris on the basement complex. The products of this latter volcanism consisted mostly of calc-alkalic basalts and a few andesites. (3) Another 125 meters of tuff and volcaniclastic breccia accumulated during the next 4.5 m.y., signifying a period of waning volcanism. (4) During this same period, the strata were tilted up to $25^{\circ}$. (5) From about $5 \mathrm{~m}$.y. ago to the present, after all volcanic activity had ceased, only calcareous biogenous sediments were deposited in the area, accompanied by very slight subsidence ( $<100$ meters).

\section{MARIANA RIDGE}

The Mariana Ridge, the island arc east of the Mariana Trough and west of the Mariana Trench, is the region of modern arc volcanism in the South Philippine Sea (Fig. 1). The trough is the current site of back-arc basin spreading. The trench defines the top of the active subduction zone that is the site of underthrusting of the Pacific plate beneath the South Philippine Sea. The ridge, upon which the volcanic edifices are built, con- 
tains the eruptive sequence. The fore-arc region, east of the volcanic arc, presumably contains vestiges of the older West Mariana fore-arc and the still older PalauKyushu fore-arc. Until recently, evidence for the early history of volcanism contained in these fore-arcs was derived mainly from the geology of the Mariana islands (Cloud et al., 1956; Schmidt, 1957; Stark, 1963; Tracy, 1964). The geology of Guam is perhaps most important, because Guam is thought to be an uplifted portion of the actual present-day fore-arc region and contains the most complete sections.

Evidence for two episodes of volcanic activity (summarized by Ingle, 1975) is present on Guam. The first is an older, tholeiitic episode that lasted from at least 42 m.y. to about 34 m.y. ago. During this time, the pillow lavas and volcaniclastic breccis and conglomerates of the Alutom Formation (the oldest formation in Guam) and the overlying tholeiitic pillow basalts, flows, and flow breccias of the lower Facipi volcanic member of the Umatac Formation were deposited. Only sporadic volcanism is recorded in this lower member from about 30 to $25 \mathrm{~m}$.y. ago. The second period of volcanic activity is a younger calc-alkalic episode, which lasted from about $17 \mathrm{~m} . \mathrm{y}$. to $13 \mathrm{~m} . \mathrm{y}$. ago, during which the upper Facipi volcanic member and the overlying basalt and andesite flows of the Dandan flow member, both of the Umatac Formation, were deposited. No record of Pleistocene activity exists on Guam.

Similar periods of volcanic activity on Saipan from about 42 m.y. to $41 \mathrm{~m}$.y. ago are represented by the andesitic flows, conglomerates, pyroclastics, and tuffs of the Densiyama and Hagman Formations and from about $17 \mathrm{~m} . \mathrm{y}$. to $14 \mathrm{~m} . \mathrm{y}$. ago by the tuffaceous facies of the Tagpochau Limestone and the flows of the Fina-sisu Formation. On Tinian only the older suite is represented by the 42- to 37-m.y.-old Tinian pyroclastic deposits. The northern Mariana Islands do, however, record the Pliocene and Pleistocene volcanism missing from the Guam section.

The drilling results of Leg 60 (Hussong, Uyeda, et al., 1978) are critical for the interpretation of modern arc and remnant arc volcanic histories of the entire Philippine Sea complex. For example, the volcaniclastic debris in Hole 453 on the western side of the Mariana Trough (Fig. 1) may contain the record of the modern period of arc volcanism that is absent from the Leg 59 holes.

SUMMARY OF ARC AND MARGINAL-BASIN EVOLUTION IN THE SOUTH PHILIPPINE SEA

The timing of changes in sedimentary facies, emplacement of igneous units, and overprinting of deformational structure is essential to interpreting the sequence of events and understanding the evolution of the South Philippine Sea arc-back-arc basin complex. The sequence of events in the formation of the South Philippine Sea complex is deduced from the results of Leg 59 drilling, site surveys for Leg 59, the results of previous drilling, the regional subaerial geology, and initial Leg 60 results (Hussong, Uyeda, et al., 1978).

(1) Late in the Paleozoic, subduction occurring along the western side of the proto-Pacific Ocean under the eastern side of the Asian plate formed the igneous and metamorphic basement of Okinawa, which is now exposed in the modern Ryukyu arc. (2) In the Mesozoic, subduction presumably continued to consume the proto-Pacific plate along the Asian continental margin (Hilde et al., 1977). It is difficult, however, to discuss the history of this region during this time, because Mesozoic rocks are not present in the Ryukyu arc nor have they been found in the West Philippine Basin. (3) During the early Tertiary, the West Philippine Basin formed, spanning a period beginning not earlier than 62 m.y. ago and ending not later than $37 \mathrm{~m} . \mathrm{y}$. ago; overlapping the critical 42-m.y. point, sea-floor spreading occurred behind the Oki Daito Ridge-a possible subduction boundary-about an axis nearly parallel to the Central Basin Ridge. No evidence exists to discriminate between a back-arc style and a mid-ocean ridge style of sea-floor spreading. A large transform fault, in the position of the present-day Palau-Kyushu Ridge, separated this system from the Pacific plate to the east. (4) About 42 m.y. ago, a change in plate motion required that the Palau-Kyushu boundary change from a transform fault to a convergent margin and become a subduction boundary. Spreading continued in the West Philippine Basin, oblique to the this newly formed subduction boundary, until about 37 m.y. ago. Because the modern Mariana arc presumably contains elements of the forearc of the original Palau-Kyushu island arc, dating of initial subduction along the Palau-Kyushu Ridge, which began in the late Eocene (about 42 m.y. ago), is based not only on the hypothesis of change in plate motion but also on the earliest record of volcanism that is preserved on Guam, Saipan, and Tinian. (5) Arc volcanism continued until the middle Oligocene, about $32 \mathrm{~m} . \mathrm{y}$. ago, as evidenced by the 32-m.y. age of the tuffs in Hole 447A and the 32-m.y. to 34-m.y. age of the flows comprising arc basement in Holes 448 and 448A. (6) During or shortly after this last major phase of arc volcanism, the region just west of the Palau-Kyushu Ridge was also affected by tectonism. (7) Tuffs accumulating on the ridge until 29 m.y. ago signaled the waning phase of arc volcanism. (8) Arc volcanism probably ceased shortly after the original Palau-Kyushu arc was sundered along its volcanic axis less than 31 m.y. ago. (9) Back-arc-basin spreading was initiated, beginning the formation of the Parece Vela Basin and driving the old fore-arc region of the Palau-Kyushu Ridge eastward. From 29 m.y. to 20 m.y. ago, however, little or no evidence of arc volcanism was preserved in either the island arc or back-arc system, a conspicuous hiatus that coincides with this early period of Parece Vela Basin back-arc spreading (Table 1). (10) About 20 m.y. ago, on back-arc-basin crust immediately behind the old, eastward-rifted Palau-Kyushu fore-arc, island-arc volcanism began again, forming the new West Mariana island arc. (11) Formation of the Parece Vela Basin continued until sometime between $18 \mathrm{~m} . \mathrm{y}$. and $14 \mathrm{~m} . \mathrm{y}$. ago, based on magnetic anomaly and geologic evidence, respectively. (12) About 17 m.y. ago, the wedge of volcaniclastic sediments in the Parece Vela Basin on the west side of the West Mariana arc was intruded off-axis by basalts 
Table 1. Events in Philippine Sea evolution. ${ }^{\mathrm{a}}$

\begin{tabular}{lrc}
\hline \multirow{2}{*}{$\begin{array}{c}\text { Marginal Basin and } \\
\text { Remnant Arc Formation }\end{array}$} & \multicolumn{2}{c}{ Timing of Events (m.y.) } \\
& Karig (1975) & This Chapter \\
\hline West Philippine Basin & $45-37$ & $52-37$ \\
Palau-Kyushu Ridge & ?early Tertiary-25 & $? 42-29$ \\
Parece Vela Basin & $25-18$ & $30-18$ to 14 \\
West Mariana Ridge & $?-5$ & $20-9$ \\
Mariana Trough & 3 to $2-0$ & $5-0$ \\
Mariana Arc & $5-0$ & $5-0$ \\
Maxima and Minima & & \\
in Arc Volcanism & & \\
\hline First maximum & & \\
First minimum & $? 46-36$ & $? 42-32$ \\
Second maximum & $35-30$ & $30-20$ \\
Second minimum & $30-12$ & $20-9$ \\
Third maximum & $10-5$ & $9-5$ \\
& $5-0$ & $5-0$ \\
\hline
\end{tabular}

a Periods of arc volcanism, marginal basin formation, and arc volcanic maxima and minima in the Philippine Sea are shown. Karig's (1975) conclusions are compared with those of this chapter. (Note that only the timing of the Palau-Kyushu arc volcanism and Parece Vela spreading differ substantially; also the first and second volcanic maxima of this chapter do not match periods of basin formation in our conclusions.)

with MOR chemical affinities. (13) About 11 m.y. to 9 m.y. ago, the waning phase of arc volcanism on the West Mariana Ridge began, coincident with tectonic deformation of the back-arc region (Table 1). (14) Roughly $5 \mathrm{~m} . \mathrm{y}$. ago, sundering of the arc formed the Mariana Trough and displaced the West Mariana forearc region to the east, which eventually became the forearc of the Mariana island arc (Hussong, Uyeda, et al., 1978). (15) Subsidence of the Parece Vela Basin followed, accompanied by slight subsidence of the West Mariana remnant arc itself at the same time the Mariana Trough was spreading. (16) In the Pliocene, volcanism began along the Mariana arc and has continued to the present day.

Paleomagnetic latitudes for rocks in Holes 447A, 448 , and $448 \mathrm{~A}$ are $5^{\circ}$ to $10^{\circ}$ from the equator (Keating and Herrero, this volume) and for rocks in Hole 450 are $0^{\circ}$ to $5^{\circ}$ (Keating, this volume) at the time of formation. Although the hemisphere cannot be determined from these data, in all four holes evidence exists that requires a significant northward plate motion from these equatorial positions to $18^{\circ} \mathrm{N}$.

In this complicated sequence of events, a few simple relationships are observed. Principally, there are periods of back-arc spreading accompanied by a marked decrease or absence of arc volcanism. Conversely, there are periods of intense arc volcanism during which there is no back-arc spreading. These observations are diametrically opposed to the cause-effect relationship that Karig proposed, in which he suggested that rapid rates of concurrent subduction, abundant volcanism, and back-arc spreading are interrelated (see Karig, 1975, pp. 874-876). Although the data available to Karig were insufficient to suggest otherwise, it is now apparent that the period of Parece Vela back-arc basin spreading does not match the period of abundant volcanism on the
West Mariana Ridge. Thus, as shown in Table 1, gaps in episodic volcanism seem to exist that are nonsynchronous with gaps of spreading.

Believing that volcanism was more or less continuous, however, Hussong and Fryer (1980) downplay both the size and significance of the gaps. The argument in favor of continuous volcanism can be made: During the stage of reinitiation of volcanism after sundering of the arc, some period of time is required to build new volcanoes from submarine basin depths to the surface in order to affect deposition by an ash influx. Such reasoning seems unlikely for the older and larger gap (about 9 m.y. long). During the latest Miocene, deposition of primary volcaniclastic debris changed to deposition of epiclastic volcaniclastic debris (Rodolfo, this volume), suggesting that after $11 \mathrm{~m} . \mathrm{y}$. ago, volcanism may have ceased on the West Mariana Ridge and that subsequent accumulation of volcaniclastic debris was the result of redeposition associated with tectonic disturbances rather than the result of continued volcanism. Such an interpretation would require a younger volcanic gap between 11 and 5 m.y. ago.

These conclusions present several interesting problems. What is the cause of the break-up of the arc along the volcanic axis, i.e., what is the mechanism for sundering the arc? If the gaps in arc volcanism are real, is there a concomitant decrease in subduction rate? It does not seem possible that the arc volcanism was somehow masked by intermixing with back-arc-basin volcanism, because the Parece Vela Basin basalts, for example, have no chemical affinities with island-arc tholeiites or calc-alkalic basalts. If subduction occurs during a lull or absence of volcanism, as appears to be the case in several modern arcs, how does this phenomenon affect our concepts of magma genesis along arcs?

It is possible that an eastward global sublithospheric flow (Seiya Uyeda, personal communication; Uyeda and Kanamori, 1979) operated to steepen westwarddipping subducting plates so that the magmas, derived from different depths on the descending slab, intruded a more narrow part of the arc. This intense concentration of magmas along the volcanic axis would thermally have weakened the arc lithosphere; the arc would have then sundered and sea-floor spreading would have begun forming the back-arc basin. Meanwhile, the descending slab could have oversteepened and broken off, interrupting the formation of arc magma until the broken upper part of the slab again reached the appropriate depth to begin forming arc magma again. The time involved in such a process would require a sublithospheric flow on the order of only 1 to $1.5 \mathrm{~cm} / \mathrm{y}$. Although such explanation is conjectural, the reason for inclusion here is to emphasize the need for a mechanism to explain the periodicity of back-arc spreading and arc volcanism. The geometric explanation of Jurdy (1979) is certainly a viable alternative interpretation of the observed asymmetry of modern back-arc basins, but it does not explain the periodicity of back-arc spreading and arc volcanism. It should be mentioned that periodicity, at least in abundance of volcanism in the circum-Pacific 
region, has been previously noted; for example, Kennett et al. (1977) recognize a maximum of volcanic activity (3-6 m.y. ago) on the Pacific plate margins.

Other problems still exist, particularly in the petrological evolution of these arcs. In many arcs, the petrologic evolution of primitive arc tholeiites to calcalkalic rocks (Miyashiro, 1974) has been observed as well as the spatial distribution of these rock types (Kuno, 1966). The basalts of the Palau-Kyushu Ridge consist primarily of arc tholeiites similar to the basalts and andesites emplaced during the first volcanic episodes on Guam. The basalts and andesites of the West Mariana Ridge are primarily calc-alkalic, like the basalts and andesites emplaced during the last episodes on Guam, and there are few, if any, arc tholeiites. These fit the usual evolutionary trends of arc volcanism but present a problem in the location of tholeiitic volcanism on the West Mariana Ridge. The igneous rocks on Saipan, however-which coincide with the first tholeiitic volcanism on Guam-have an $\mathrm{Al}_{2} \mathrm{O}_{3}$ range of $16.4 \%$ to $19.0 \%$. This range appears to be more calc-alkalic in nature than tholeiitic (Schmidt, 1957), even though the Saipan rocks are closer to the subduction zone than are the tholeiites of the Palau-Kyushu Ridge. The basaltic and andesitic Quaternary volcanoes of the northern Mariana islands, which also appear to be calc-alkalic $\left(\mathrm{Al}_{2} \mathrm{O}_{3}\right.$ values ranging from 16.9 to $21.2 \mathrm{wt}$. \%), create a similar problem - the apparent lack of a tholeiitic belt of volcanism closer to the subduction zone. Obviously, the timing and spatial relationships of magmatic evolution of arcs still need considerable study (Arculus, 1976; Arculus and Johnson, 1978; Miyashiro, 1974).

Another problem associated with petrological evolution of the arcs is the abundance of high-magnesium andesites or boninites observed in the arc and fore-arc region of the active Mariana Ridge (Hussong, Uyeda, et al., 1978; Hussong, Uyeda, et al., in press). Meijer (in press) and Meijer et al. (in press) have suggested that these boninites may be the hydrous melting products of the lithosphere overlying the subduction zone in an abnormally high geothermal gradient. Another explanation may lie in the nature of the Palau-Kyushu boundary prior to $42 \mathrm{~m} . \mathrm{y}$. ago. Many large transform faults contain serpentine diapirs, which reflect hydration of the mantle along these zones (Bonatti and Honnorez, 1976). If the mantle along the Palau-Kyushu boundary were serpentized during the formation of the transform fault, it would provide a ready source for a depleted hydrous $\mathrm{Mg}$-rich magma during later subduction.

\section{ACKNOWLEDGMENTS}

We wish to thank Glyn Jones and Tom Hilde for their suggestions and critical review. Also, Dan Karig, Don Hussong, and George Klein have all contributed to our synthesis. Finally, this chapter could not have been formulated without the efforts of our shipboard scientists. This chapter is Texas A\&M Geodynamics Research Program Contribution Number 0013.

\section{REFERENCES}

Arculus, R. J., 1976. Geology and geochemistry of the alkali basaltandesite association of Grenada, Lesser Antilles island arc. Geol. Soc. Am. Bull., 87:612-624.
Arculus, R. J., and Johnson, R. W., 1978. Criticism of generalized models for the magmatic evolution of arc-trench systems. Earth Planet. Sci. Lett., 39:118-126.

Ben-Avraham, Z., Bowin, C., and Segawa, J., 1972. An extinct spreading center in the Philippine Sea. Nature, 240:453-455.

Blanchard, D. P., Rhodes, J. M., Dungan, M. A., et al., 1976. The chemistry and petrology of basalts from Leg 37 of the DSDP. $J$. Geophys. Res., 81:4231-4349.

Bonatti, E., and Honnorez, J., 1976. Sections of the earth's crust in the equatorial Atlantic. J. Geophys. Res., 81:4104-4116.

Bowin, C., and Reynolds, P. H., 1975. Radiometric ages from the Ryukyu arc region and an ${ }^{40} \mathrm{Ar} /{ }^{39} \mathrm{Ar}$ age from biotite dacite on Okinawa. Earth Planet. Sci. Lett., 27:363-370.

Cloud, P. E., Jr., Schmidt, R. G., and Burke, H. W., 1956. Geology of Saipan, Mariana Islands. Part 1, General Geology. U.S. Geol. Survey Prof. Paper, 280-A:1-126.

Dick, H. J. B., in press. Vesicularity of Shikoku Basin basalt: a possible correlation with the anomalous depth of back-arc basins. In Klein, G. deV., Kobayashi, K., et al., Init. Repts. DSDP, 58: Washington (U.S. Govt. Printing Office).

Dick, H. J. B., Marsh, N. G., and Bullen, T. D., in press. DSDP Leg 58 abyssal basalts from the Shikoku Basin: their petrology and major element geochemistry. In Klein, G. deV., Kobayashi, K., et al., Init. Repts. DSDP, 58: Washington (U.S. Govt. Printing Office).

Dick, H., Marsh, N. G., and Nisterenko, G. V., 1978. Extensial volcanism in the Shikoku Basin. Trans. Am. Geophys. Union, EOS, 59:1187.

Dietrich, V., Emmermann, R., Oberhansli, R., et al., 1978. Geochemistry of the basaltic and gabbroic rocks from the West Mariana Trench. Earth Planet. Sci. Lett., 39:127-144.

Dungan, M. A., and Rhodes, J. M., 1978. Residual glasses and melt inclusions in basalts from DSDP Legs 45 and 46: evidence of magma mixing. Contrib. Mineral. Petrol., 87:417-431.

Erlank, A. J., and Kable, E. J. D., 1976. The significance of incompatible elements in mid-Atlantic ridge basalts from $45^{\circ} \mathrm{N}$ with particular reference to $\mathrm{Zr} / \mathrm{Nb}$. Contrib. Mineral. Petrol., 54:281-291.

Fischer, A. G., Heezen, B. C., et al. 1971. Init. Repts. DSDP, 6: Washington (U.S. Govt. Printing Office).

Harian, A. M., 1968. Bathymetry and Sub-bottom Profiling; Marine Geophysical Program 65-67 Area 12 (Vol. 3): Washington (U.S. Naval Oceanog. Off.).

Hart, S. R., 1971. K, Rb, Cs, $\mathrm{Sr}$ and $\mathrm{Ba}$ contents and $\mathrm{Sr}$ isotope ratios of ocean floor basalts. Phil. Trans. Roy. Soc. London A, 268:573-587.

Hawkins, J. W., 1976. Petrology and geochemistry of basaltic rocks of the Lau Basin. Earth Planet. Sci. Lett., 28:38-40.

1977. Petrologic and chemical characteristics of marginal basin basalts. In Talwani, M., and Pitman, W. C., III (Eds.), Island Arcs, Deep Sea Trenches and Back-Arc Basins: Washington (Am. Geophys. Union), pp. 355-365.

Hess, H. H., 1948. Major structural features of the western North Pacific, an interpretation of H.O. 5485, bathymetric chart, Korea to New Guinea. Geol. Soc. Am. Bull., 59:417-466.

Hilde, T. W. C., Uyeda, S., and Kroenke, L., 1977. Evolution of the Western Pacific and its margin. Tectonophysics, 38:145-165.

Hussong, D. M., and Fryer, P., 1980. Tectonic evolution of the marginal basins behind the Mariana arc. Geol. Soc. Am. Abstracts with Programs, 12:1112.

Hussong, D., Uyeda, S., et al., 1978. Leg 60 ends in Guam. Geotimes, 23 (10): 19-22.

, in press. Init. Repts. DSDP, 60: Washington (U.S. Govt. Printing Office).

Ingle, J. C., Jr., 1975. Summary of late Paleogene-Neogene insular stratiography, paleobathymetry, and correlations, Philippine Sea and Sea of Japan region. In Ingle, J. C., Jr., Karig, D. E., et al., Init. Repts. DSDP, 31: Washington (U.S. Govt. Printing Office), 837-855.

International Working Group on the IGCP Project "Ophiolites," 1977. Initial report of the geological study of oceanic crust of the Philippine Sea floor. In Bogdanov, N. (Ed.), Bollettino del Grupo di Lavoro aulle Ofioliti Mediterranee (Vol. 2): Bologna (Estratto da Ofioliti), 137-168.

Jakeš, P., and Gill, J., 1970. Rare earth elements and the island arc tholeiitic series. Earth Planet. Sci. Lett., 9:17-28. 
Jakeš, P., and White, A. J. R., 1972. Major and trace element abundances in volcanic rocks of orogenic areas. Geol. Soc. Am. Bull., $83: 29-40$.

Jurdy, D. M., 1979. Relative plate motions and the formation of marginal basins. J. Geophys. Res., 84:6796-6801.

Karig, D. E., 1971. Site surveys in the Mariana Area (Scan IV). In Fischer, A. G., Heezen, B. C., et al., Init. Repts. DSDP, 6: Washington (U.S. Govt. Printing Office), 681-689.

1974. Evolution of arc systems in the western Pacific. Ann. Rev. Earth Planet. Sci., 2:51-75.

1975. Basin genesis in the Philippine Sea. In Ingle, J. C., Jr., Karig, D. E., et al., Init. Repts. DSDP, 31: Washington (U.S. Govt. Printing Office), 857-879.

Karig, D. E., and Glassley, W. E., 1970. Dacite and related sediment from the West Mariana Ridge, Philippine Sea. Geol. Soc. Am. Bull., 81:2143-2146.

Karig, D. E., Ingle, J. C., Jr., et al., 1975. Init. Repts. DSDP, 31: Washington (U.S. Govt. Printing Office).

Kennett, J. P., McBirney, A. R., and Thunell, R. C., 1977. Episodes of Cenozoic volcanism in the circum-Pacific region. J. Volc. Geoth. Res., 2:145-163.

Klein, G. deV., Kobayashi, K., et al., in press. Init. Repts. DSDP, 58: Washington (U.S. Govt. Printing Office)

1978a. Philippine Sea drilled. Geotimes, 23(5):23-25. 1978 b. Off-ridge volcanism and seafloor spreading in the Shikoku Basin. Nature, 273:746-748.

Kuno, H., 1966. Lateral variation of basalt magma type across continental margins and island arcs. Bull. Volcanol., 29:195-222.

Lee, C. S., Shore, G. G., Bibee, L. D., et al., in press. Okinawa Trough: origin of a back-arc basin. Mar. Geol.

Louden, K. E., 1976. Magnetic anomalies in the West Philippine Basin. In Sutton, G. H., Manghnani, M. H., and Moberly, R (Eds.), The Geophysics of the Pacific Ocean Basin and Its Margin: Geophys. Monogr. Ser. 19: Washington (Am. Geophys. Union), pp. 253-267.

Meijer, A., 1976. $\mathrm{Pb}$ and $\mathrm{Sr}$ isotopic data bearing on the origin of volcanic rocks from the Mariana island-arc system. Geol. Soc. Am. Bull., 87:1358-1369.

, in press. Primitive arc volcanism and a boninite series: examples from western Pacific island arcs. Earth Planet. Sci. Lett.

Meijer, A., Anthony, E. Y., and Reagan, M., in press. Petrology of volcanic rocks from the fore-arc sites. In Hussong, D. M., Uyeda, S., et al., Init. Repts. DSDP, 60: Washington (U.S. Govt. Printing Office).

Miyashiro, A., 1974. Volcanic rock series in island arcs and active continental margins. Am. J. Sci., 274:321-355.

Murauchi, S., Den, N., Asano, S., et al., 1968. Crustal structure of the Philippine Sea. J. Geophys. Res., 73:3143-3171.

Rhodes, J. M., Blanchard, D. P., Rodgers, K. V., et al., 1976. Petrology and chemistry of basalts from the Nazca Plate: Part 2, major and trace element chemistry. In Hart, S. R., Yeats, R. S., et al., Init. Repts. DSDP, 34: Washington (U.S. Govt. Printing Office), 239-244.

Ridley, W. I., Rhodes, J. M., Reid, A. M., et al., 1974. Basalts from Leg 6 of the Deep-Sea Drilling Project. J. Petrol., 15:140-159.

Schmidt, R. G., 1957. Petrology of the volcanic rocks. Part 2, Petrology and soils: geology of Saipan, Mariana Islands. U.S. Geol. Survey Prof. Paper, 280-B:127-175.

Sclater, J. G., Karig, D., Lawyer, L. A., et al., 1976. Heat flow, depth and crustal thicknesses of the marginal basins of the South Philippine Sea. J. Geophys. Res., 81:309-318.

Seekins, L. C., and Teng, T. L., 1977. Lateral variations in the structure of the Philippine Sea plate. J. Geophys. Res., 82:317-324.

Shih, T.-c., 1978. Marine magnetic anomalies from the Western and Northern Philippine Sea [Ph.D. dissert.]. University of Texas, Austin.

, in press. Magnetic lineations in the Shikoku Basin. In Klein, G. deV., Kobayashi, K., et al., Init. Repts. DSDP, 58: Washington (U.S. Govt. Printing Office).

Stark, J. T., 1963. Petrology of the volcanic rocks of Guam. U.S. Geol. Survey Prof. Paper, 403-C:C1-C32.

Stern, R. J., 1979. On the origins of andesite in the northern Mariana Island Arc: implications from Agrigan. Contrib. Mineral. Petrol. $68: 207-219$

Tracey, J. I., Jr., Seymour, O. S., Stark, J. T., et al., 1964. General geology of Guam. U.S. Geol. Survey Prof. Paper, 403-A:A1-A104.

Uyeda, S., and Kanamori, H., 1979. Back-arc opening and the mode of subduction. J. Geophys. Res., 84:1049-1061.

Watanabe, T., Langseth, M. G., and Anderson, R. N., 1977. Heat flow in back-arc basins of the Western Pacific. In Talwani, M., and Pitman, W. C., III (Eds.), Island Arcs, Deep Sea Trenches and Back-Arc Basins: Washington (Am. Geophys. Union), pp. 137-161.

Watts, A. B., and Weissel, J. K., 1975. Tectonic history of the Shikoku marginal basin. Earth Planet. Sci. Lett., 25:239-250.

Watts, A. B., Weissel, J. K., and Larson, R. L., 1977. Sea-floor spreading in marginal basins of the western Pacific. Tectonophysics, 37:167-181.

White, W. M., and Bryan, W. B., 1977. Sr-isotope, K, Rb, Cs, Sr, Ba, and rare-earth geochemistry of basalts from the FAMOUS area. Geol. Soc. Am. Bull., 88:571-576.

Wood, D. A., Varet, J., Bougault, H., et al., 1979. The petrology and geochemistry of North Atlantic basalts: a discussion based on IPOD Leg 49. In Luyendyk, B., Cann, J. R., Init. Repts. DSDP, 49: Washington (U.S. Govt. Printing Office), 597-655.

Wood, D. A., Tarney, J., Varet, J., et al., 1979. Geochemistry of basalts drilled in the North Atlantic by IPOD Leg 49: Implications for mantle heterogeneity. Earth Planet. Sci. Lett., 42:77-97. 